\title{
KESANTUNAN BERBAHASA DALAM TUTURAN NOVEL PERSONIFIKASI SASTRA DAN FILSAFAT
}

\author{
Welly Santiung ${ }^{1}$ \\ UPBJJ-UT Makassar \\ Program Studi: Bahasa Indonesia \\ Email :wellys@ecampus.ut.ac.id
}

\begin{abstract}
ABSTRAK
Novel menggunakan tuturan dan percakapan yang memenuhi prinsip kesantunan berbahasa. Permasalahan dalam penelitian ini yaitu: bagaimana penggunaan kesantunan berbahasa. Tujuan penelitian ini adalah untuk mendeskripsikan kesantunan berbahasa. Menganalisis data kemudian diinterpretasikan menurut prinsip kesantunan berbahasa. Ketika kita membaca sebuah karya sastra, tentunya kita dapat melihat betapa indah karya sastra itu dengan gaya tulisannya masing masing. Keindahan itu dapat kita lihat mulai dari penuturan ide yang menggunakan simbol tertentu, alur atau jalan cerita yang unik, hingga pada konklusi dari cerita tersebut dibuat. Setiap penulis memiliki hak untuk membuat karyanya menjadi sesuatu yang bermakna dan dapat mempengaruhi masyarakat.

Secara asasi, baik karya sastra maupun filsafat merupakan suatu hasil refleksi penulisan ini atas keberadaan manusia. Hanya saja, jika sastra merupakan refleksi evaluatif, filasafat merupakan refleksi kritis. Harus diakui bahwa diantara karya sastra sejenis itu, terdapat karya yang lebih mengedepankan filsafat daripada sastranya atau sebaliknya. Dalam konteks itu, gagasan filsafat yang dibungkus ke dalam kemasan sastra haruslah tetap ditempatkan sebagai karya sastra. Gagasan yang terkandung dalam karya itu seyogianya menjadi bagian yang tak terpisahkan dari unsur kesastraan lainnya. Dengan demikian, gagasan filsafat akan melebur menjadi salah satu unsur yang justru ikut membangun nilai nilai estetika karya yang bersangkutan.
\end{abstract}

Kata kunci: Novel, Kesantunan, Sastra, Filsafat.

\section{PENDAHULUAN}

Dalam dunia sastra, bahasa merupakan alat utama untuk berkomunikasi dalam kehidupan manusia, baik secara individual maupun secara sosial. Salah satu aspek penggunaan bahasa dalam bentuk penelitiann ialah karya sastra. Bahasa dalam sastra menjadi alat manusia untuk menyatakan pera-saan, pikiran, 
dan angan-angannya (Alisjahbana, 1977:51). Penelitian ini penting dilakukan karena semakin berkurangnya minat membaca pa-da anak serta kurangnya buku bacaan anak yang berkualitas sehingga diharapkan dengan penelitiann ini anakanak menjadi tertarik dengan buku bacaan yang sesuai dengan umur mereka.

Umumnya karya sastra merupakan salah satu penyaluran pesan yang efektif untuk menyampaikan berbagai masalah serta solusi di dalam kehi-dupan. Penyampaian pesan ini bisa kita sampaikan ke berbagai lapisan masyarakat, baik orang dewasa maupun anak-anak. Pesan yang disampaikan ini diharapkan memberikan dampak terhadap pembaca agar pesan yang dikandung dalam karya sastra betul-betul tersampaikan. Salah satu karya sastra yang cukup efektif dalam menyampaikan pesan-pesan dalam kehidupan adalah novel. Dalam penelitiann ini, peneliti mengorientasikan kajian terhadap novel berupa buku cerita anak. Penelitiann tentang kesantunan berbahasa pada buku cerita ini penting karena anak pada dasarnya adalah peniru yang baik, jadi dengan ditelitinya kesantunan berbahasa pada buku cerita anak ini, diharapkan anak punya teladan yang baik untuk mereka tiru, terutama pada buku cerita anak.

Hakikat novel merupakan salah satu karya sastra kreatif yang berbentuk prosa. Berbeda dengan puisi dan drama, prosa lebih menonjolkan sisi narasinya. Begitu juga dengan novel, ia tidak dapat dibaca hanya dengan "sekali duduk" sebab novel pendeskripsiannya lebih detail dan lebih panjang alurnya dibandingkan cerpen. Salah satu ciri khas yang segera dapat kita saksikan dari karangan jenis ini ialah bentuknya yang bersifat pembeberan. Melalui karyanya tersebut seakan-akan pengarang berusaha menguraikan seluruh ungkapan perasaan dan pikirannya secara terperinci. Segala peristiwa dan kejadian serta keseluruhan jalan hidup tokoh ceritanya diuraikan sedemikian rupa sehingga pembaca dapat mengikuti dan memahaminya (Suharianto 2005:40).

Permasalahan dalam penelitiann ini dapat dirumuskan sebagai berikut. (1) Jenis tuturan apa saja dalam kesantunan berbahasa?, (2) Bagaimana karakteristik tuturan dalam kesantunan berbahasa?, (3) Bagaimana strategi penutur dalam mewujudkan kesantunan berbahasa?

Tujuan penelitiann ini meliputi tiga hal sebagai berikut; (1) Mendeskripsi dan mengidentifikasi jenis tuturan dalam kesantunan berbahasa; (2) Mendeskripsi karakteristik tuturan dalam kesantunan berbahasa; dan (3) Mendeskripsi dan menelaah strategi penutur dalam mewujudkan kesantunan berbahasa.

Penelitiann berjudul Tindak Tutur Percakapan dalam Novel Sekayu Karya Nh. Dini dipaparkan oleh Tresnawati (1998). Penelitiann ini mendeskripsi pemakaian tindak tutur, yaitu tindak tutur representatif, direktif, ekspresif, komisif, dan deklarasi yang didasarkan pada tindak tutur menurut Searle. Jenis tindak tutur tersebut membentuk satu komposisi atau susunan. Komposisi jenisjenis tuturan yang muncul dalam novel sekayu bervariasi antara tindak tutur representatif, tindak tutur ekspresif, dan tindak tutur ekspresif.

Kekooperatifan dan kesantunan dalam media iklan diteliti oleh Pirman (Alviah, 2014). Judul tesis yang ditulis Pirman adalah Kekooperatifan dan Kesantunan Iklan Radio dan Televisi Berbahasa Indonesia. Hasil penelitiann ini bahwa ketidakpatuhan terhadap prinsip kerjasama dan kesantunan terjadi tidak 
hanya dalam kehidupan sehari- hari, tetapi juga terjadi dalam iklan radio dan televisi. Jika bahasa iklannya tidak atau kurang santun, bahasa masyarakatpun akan ikut- kurang atai tidak santun.

Rahardi (2000) dalam penelitiannnya yang berjudul Imperatif dalam Bahasa Indonesia. Mengungkapkan kesantunan pemakaian tuturan imperatif bahasa Indonesia dapat mencakup dua macam perwujudan, yakni kesantunan pragmatik dan kesantunan linguistik. Kesantunan pragmatik diwujudkan dalam dua macam wujud tuturan, yakni tuturan deklaratif bermakna pragmatik imperatif dan tuturan interogatif bermakna pragmatik imperatif. Sedangkan kesantunan tuturan linguistik ditandai panjang pendek tuturan, urutan tuturan, intonasi tuturan, isyarat-isyarat dan penanda kesantunan.

Variasi tuturan pada novel melalui penelitiann Kevariasian Tindak tutur Percakapan Tokoh Utama Wanita dalam Novel-novel Karya Pengarang Wanita dipaparkan oleh Budiyati (2001). Dari hasil penelitiann itu, jenis tindak tutur representatif, direktif, ekspresif, komisif, dan deklaratif terdapat pada empat novel yang diteliti. Komposisi jenis tindak tutur tidak sama, artinya pada novel yang dikaji terdapat perbedaan jumlah komposisi yang tidak sama. Pada penelitiann tersebut belum diungkap jenis, frekuensi, dan fungsi tindak tutur percakapan diaplikasikan pada interaksi pembelajaran.

Riniwati (Alviah, 2014: 130) meneliti tuturan pada media cetak dengan judul Fungsi tuturan, Variasi tuturan, dan Implikatur dalam Wacana Wayang Mbeling di Harian suara Merdeka. Terdapat lima fungsi tuturan, yaitu: mengungkapkan, memberitahukan, menyelidiki, membujuk, dan menyenangkan. Variasi tuturan mencakup masyarakatnya (usia, jenis kelamin, etnik, status sosial, hubungan kekerabatan, kreativitas); penutur dan pemakainya (variasi berdasar penutur dan pemakainya); dan implikatur (implikatur percakapan khusus dan implikatur percakapan umum).

Penggunaan tuturan dalam novel diteliti oleh Sawali (2007) dalam judul Karakteristik, Fungsi, dan Latar Belakang Penggunaan Tuturan yang Mengandung Informasi Percakapan dalam Novel Belantik. Karakteristik tuturan yang mengandung kekeliruan inferensi percakapan dipilah ke dalam empat kelompok atas dasar situasi tutur, jenis tuturan, pelanggaran prinsip kerjasama, dan pelanggaran prinsip kesantunan. Adapun fungsi tuturan yang mengandung kekeliruan inferensi percakapan adalah sebagai pemicu konflik eksternal dan pemicu konflik internal. Fungsi sebagai pemicu konflik eksternal yang berupa konflik fisik tidak ditemukan. Hal-hal yang melatar belakangi penggunaan tuturan yang mengandung kekeliruan inferensi percakapan adalah penggambaran karakter tokoh, penyampaian pesan moral, penggambaran ketimpangan sosial, penggambaran kebiasaan tokoh, penggambaran nilai-nilai budaya, penggambaran perbedaan status sosial, dan penggambaran gaya hidup tokoh.

Tindak tutur pada wacana panatacara diteliti oleh Supriyono (Alviah, 2014: 131) dengan judul Jenis dan Fungsi Tindak tutur dan Gaya Bahasa pada Wacana Panatacara. Terdapat beberapa jenis tindak tutur dalam wacana panatacara, yakni; jenis tindak tutur direktif, lokusi, perlokusi, dan ekspresif. Jenis gaya bahasa yang digunakan adalah metafora, simile, personifikasi, hiperbola, dan 
metonimi. Fungsi gaya bahasa dalam panatacara adalah fungsi estetis atau fungsi keindahan dan fungsi pragmatik (sebagai sarana mengucap syukur kepada Tuhan, upacara adat, mengangkat derajat, memberi informasi, dan sarana estetika).

Kesantunan dalam berbahasa yang terdapat dalam buku cerita anak ini merupakan sa-lah satu pesan yang secara tidak langsung disampaikan di dalam sebuah buku cerita anak. Teori kesantunan yang digunakan dalam penelitian ini ialah teori kesantunan dari Leech. Dalam model kesantunan Leech (Rahardi 2008: 66-67), setiap maksim interpersonal itu dapat dimanfaatkan untuk menentukan peringkat kesantunan sebuah tuturan. Dengan menggunakan tindak tutur, kita dapat melihat skala kesantunan teori Leech.

Kerangka teoretis yang digunakan dalam penelitiann ini meliputi (1) pengertian pragmatik, (2) tindak tutur, (3) tindak tutur langsung dan tindak tutur tidak langsung, (4) kesantunan berbahasa, (5) prinsip kerja sama, (6) prinsip kesantunan berbahasa, (7) parameter kesantunan berbahasa, dan (8) novel.

Tindak tutur mengandung beragam maksud yang dapat diidentifikasi dengan mempertimbangkan konteks pertuturannya. Di samping itu, penutur memunculkan tindak tutur itu dengan tujuan tertentu. Tindak tutur ini salah satunya dapat dikreasikan oleh peserta tutur guna menciptakan strategi-strategi dalam mewujudkan kesantunan berbahasa. Penutur memiliki kebebasan untuk berkreasi menciptakan strategi- strategi dalam mewujudkan kesantunan berbahasa tersebut. Strategi ini akan tercipta ketika tuturan diukur dalam skala atau parameter kesantunan berbahasa. Parameter digunakan untuk mengidentifikasi tuturan langsung maupun tuturan tak langsung dalam mewujudkan sebuah kesantunan berbahasa. Pada akhirnya, kesantunan ini diarahkan untuk satu tujuan pokok, yakni mewujudkan keharmonisan antara peserta pertuturan dengan menghindari hal- hal negatif dari interaksi tersebut.

\section{METODE PENELITIAN}

Pendekatan penelitian ini menggunakan pendekatan pragmatik. Pendekatan pragmatik memberikan perhatian utama kepada pembaca. Menurut Fananie (2004:114), pendekatan pragmatik yaitu pendekatan yang didasarkan pada pembaca. Keberhasilan satu karya sastra diukur dari pembacanya. Walaupun dimensi pragmatik meliputi pengarang dan pembaca, pembacalah yang lebih dominan. Karena pembaca sebagai penentu pemahaman karya satra, kemampuan kebahasaan pembaca sangat menentukan. Pendekatan pragmatik secara keseluruhan berfungsi untuk menopang teori resepsi, teori sastra yang memungkinkan pemahaman hakikat karya sastra tanpa batas. Pendekatan pragmatik mempertimbangkan implikasi pembaca melalui benbagai kompetensinya. Dengan mempertimbangkan indikator karya sastra dan pembaca, maka masalah-masalah yang dapat dipecahkan melalui pendekatan pragmatik, di antaranya benbagai tanggapan masyarakat tertentu terhadap sebuah karya sastra. 


\section{PEMBAHASAN}

Tindak tutur merupakan produk dari suatu tuturan dalam konteks tertentu dan merupakan kesatuan terkecil dalam komunikasi. Menurut para ahli, tindak tutur terdiri atas berbagai macam kategori. Analisis tindak tutur dalam penelitian ini memusatkan pembahasaan pada tindak tutur ilokusi. Tindak tutur ilokusi merupakan bagian sentral dalam memahami tindak tutur (Wijana dan Rohmadi, 2009:23). Tindak tutur tersebut dalam konteks tertentu dapat menciptakan kesantunan berbahasa bagi penuturnya. Kesantunan suatu tuturan ditentukan berdasarkan parameter- parameter kesantunan. Selanjutnya, peserta pertuturan dapat memanfaatkan berbagai macam strategi guna mewujudkan kesantunan berbahasa ini melalui tindak tutur yang diujarkannya.

Berdasarkan temuan penelitiann di atas, beberapa interpretasi dapat diungkapkan. Pertama, jenis tindak tutur ekspresif memperlihatka jumlah yang paling banyak di bandingkan tindak tutur lainnya. Hal ini menegaskan bahwa tuturan dalam novel bercirikan ekspresif. Dominannya tuturan ini disebabkan oleh pengarang yang menjadikan novel sebagai tempat untuk mengekspresikan ide, gagasan, perasaan, dan pikirannya. Pengarang mengekspresikan keempatnya dalam wujud narasi maupun pemakaian tuturan monolog dan dialog. Pemakaian tuturan monolog dan dialog yang sesuai untuk menyalurkan ekspresi pengarang tersebut adalah tuturan berjenis ekspresif, yakni jenis tuturan yang digunakan untuk mengekspresikan kondisi psikologis penuturnya.

Kedua, perwujudan kesantunan berbahasa paling banyak terjadi dalam tindak tutur jenis direktif. Kesantunan merupakan ciri yang melekat pada tindak tutur direktif. Tindak tutur direktif merupakan tindak tutur yang mengharuskan seseorang melakukan suatu perbuatan. Tujuan tindak tutur tersebut berpeluang menciptakan perselisihan atau pemaksaan terhadap salah satu pihak dalam pertuturan. Untuk itu, pemilihan tuturan yang santun dapat dijadikan alat guna menghindari atau menghilangkan hal negatif yang dapat timbul dalam tindak direktif.

Strategi mewujudkan kesantunan bersifat bebas. Artinya, penutur dapat mengkreasikan bahasa untuk mencapai kesantunan berdasarkan kemampuan berbahasa dan kebudayaan yang dimilikinya. Faktor kebahasaan bertumpu pada kemampuan memilih kata yang tepat. Di sisi lain, faktor budaya bertolak dari sifat-sifat kebudayaan tertentu. Apa yang dianggap santun dalam pendukung budaya tertentu belum tentu dianggap santun oleh pendukung budaya lainnya. Temuan penelitiann ini menyebutkan bahwa strategi mewujudkan kesantunan berbahasa dengan tuturan tidak langsung mendominasi daripada strategi lainnya. Latar belakang budaya Jawa disinyalir sebagai faktor banyaknya pemakaian strategi ini. Pengarang novel Para Priyayi dilahirkan dan hidup di dalam budaya Jawa sehingga mempengaruhi tindak tanduknya, termasuk bentuk pertuturannya. Di samping itu, latar cerita novel terjadi dalam lingkup budaya Jawa. Dengan demikian, tuturan tidak langsung berhubungan erat dengan budaya Jawa. Orang Jawa memiliki kecenderungan menggunakan tuturan tidak langsung untuk menyampaikan suatu maksud tertentu dibandingkan dengan kebudayaan lainnya. 
Novel adalah salah satu bentuk dari sebuah karya sastra. Novel merupakan cerita fiksi dalam bentuk penelitiann atau kata-kata dan mempunyai unsur instrinsik dan ekstrinsik. Sebuah novel biasanya menceritakan tentang kehidupan manusia dalam berinteraksi dengan lingkungan dan sesamanya. Dalam sebuah novel, si pengarang berusaha semaksimal mungkin untuk mengarahkan pembaca kepada gambaran-gambaran realita kehidupan melalui cerita yang terkandung dalam novel tersebut.

Novel berasal dari bahasa Itali novella yang berarti "sepotong kisah atau berita". Kemudian, kata itu diartikan sebagai sebuah karya sastra dalam bentuk prosa. Jepang adalah tempat lahir novel yang pertama. Novel itu berjudul Hikayat Genji, yang ditulis pada abad ke-11 oleh Murasaki Shikibu. (http://www.ejurnal.com/2018/11/pengertian-novel-menurut-para-ahli.html).

Seluruh ilmu hakikatnya berasal dari filsafat. Darinyalah seluruh ilmu berasal, darinya pula seluruh ilmu dan pengetahuan manusia dilahirkan. Sikap dasar selalu bertanya menjadi ciri filsafat, menurun pada berbagai cabang ilmu yang semula berinduk padanya. Karenanya, dalam semua ilmu terdapat kecenderungan dasar itu. Manakala ilmu mengalami masalah yang sulit dipecahkan, ia akan kembali pada filsafat dan memulainya dengan sikap dasar untuk bertanya. Dalam filsafat, manusia mempertanyakan apa saja dari berbagai sudut, secara totalitas menyeluruh, menyangkut hakikat inti, sebab dari segala sebab, mancari jauh ke akar, hingga ke dasar.

Karya sastra yang pada hakekatnya adalah tulisan termasuk katagori ilmu. Sebuah tulisan mempunyai sifat pragmatis dan paradoksial. Di satu sisi memberikan sebuah keniscahyaan terhadap perkembangan peradaban umat manusia, namun di sisi lain dapat menjadi alat yang ampuh untuk menggantikan sebuah ingatan kolektif sebuah masyarakat dengan cara menggantikan tulisantulisan lama dengan tulisan-tulisan baru yang bertujuan untuk menegasi ingatan masa lalu dan masa kini. Sehingga sebuah realitas baru tercipta untuk tujuan tertentu, biasanya pola-pola tersebut dipraktekkan oleh rezim-rezim totaliter untuk melanggengkan kekuasaannya. Hal tersebut memang terjadi, dan benar-benar terjadi, dan jika hal tersebut terjadi, maka akan lahir sebuah realitas tandingan berupa tulisan pula yang tidak tersurat namun tersirat.

Tulisan melahirkan berbagai macam bentuknya, salah satunya adalah yang disebut sebagai sastra. "Sastra merupakan kata serapan dari bahasa Sanskerta sastra, yang berarti "teks yang mengandung instruksi" atau "pedoman", dari kata dasar śāstra yang berarati "instruksi" atau "ajaran". Dalam bahasa Indonesia kata ini biasa digunakan untuk merujuk kepada "kesusastraan" atau sebuah jenis tulisan yang memiliki arti atau keindahan tertentu" (http://id.wikipedia.org/wiki/Sastra).

Dalam sebuah karya sastra yang merupakan sebuah bentuk imajinasi manusia yang terlahir melalui sebuah tulisan. Makna-makna untuk membidani sebuah realitas tandingan selalu tersirat di dalamnya dalam diksi yang memiliki daya pikat estetis. Sastra adalah perwujudan pikiran dalam bentuk tulisan. Tulisan sendiri adalah sebuah media tempat tercurahnya ide-ide abstrak yang mempunyai subtansi filosofis. Dengan demikian sebuah karya dan kenyataan akan kebenaran 
menjulang diantara belantara metafora dan diksi yang memiliki nilai estetis yang tinggi.

\section{MACAM-MACAM NOVEL}

\section{Novel Romantis}

Novel romantis adalah novel yang memuat cerita panjang bertemakan percintaan. Novel ini hanya dibaca khusus oleh para remaja dan orang dewasa. Alur ceritanya pertemuan kedua tokoh yang berlawanan jenis tersebut ditulis semenarik mungkin. Lalu dilanjutkan dengan konflik-konflik percintaan hingga mencapai sebuah titik klimaks, lalu diakhiri dengan sebuah ending yang kebanyakan bercabang jadi tiga: happy ending (dua tokoh utama bersatu), sad ending (dua tokoh utama tidak bersatu), dan ending menggantung (pembaca dibiarkan menyelesaikan sendiri kisah itu).

\section{Novel Komedi}

Novel komedi adalah novel yang memuat cerita yang humoris (lucu) dan menarik dengan gaya bahasa yang ringan dengan diiringi gaya humoris dan mudah dipahami.

\section{Novel Religi}

Novel ini bisa saja merupakan kisah romantis atau inspiratif yang ditulis lewat sudut pandang religi. Atau novel yang lebih mengarah kepada religi meski tema tersebut beragam.

\section{Novel Horor}

Novel ini biasanya bercerita seputar hantu. Sisi yang menarik dari novel ini adalah latar tempatnya, yang kebanyakan sebagai sumber hantu itu berasal. Cerita juga biasa disajikan dalam bentuk perjalanan sekelompok orang ke tempat angker.

\section{Novel Misteri}

Novel ini adalah novel yang biasanya memuat teka-teki rumit yang merespons pembacanya untuk berpartisipasi dalam menyelesaikan masalah tersebut. Bersifat mistis, dan keras.Tokoh-tokoh yang terlibat biasanya banyak dan beragam, seperti polisi, detektif, ilmuwan, budayawan, dll.

\section{Novel Inspiratif}

Novel Inspiratif adalah novel yang menceritakan sebuah cerita yang bisa memberi inspirasi pembacanya. Biasanya novel inspiratif ini banyak yang berasal dari cerita nonfiksi atau nyata. Tema yang disuguhkan pun banyak, seperti tentang pendidikan, ekonomi, politik, prestasi, dan percintaan. Gaya bahasanya pun kuat, deskriptif, dan akhirnya menemui karakter tokoh yang tak terduga.

\section{UNSUR INTRINSIK DAN EKSTRINSIK NOVEL}

\section{Unsur Intrinsik Novel}

Maksud unsur-unsur intrinsik dalam sebuah karya sastra adalah unsurunsur pembangun karya sastra yang dapat ditemukan di dalam teks karya sastra itu sendiri, sebagai berikut : 


\section{a. Tema (Theme)}

Gagasan, ide, atau pikiran utama yang mendasari suatu karya sastra disebut tema. Atau gampangnya, tema adalah sesuatu yang menjadi dasar cerita, sesuatu yang menjiwai cerita, atau sesuatu yang menjadi pokok masalah dalam cerita. Tema merupakan inti atau pokok persoalan yang menjadi dasara pengembangan cerita. Tema menyngkut segala persoalan, baik masalah kemanusiaan, kekuasaan, kasih sayang, kecemburuan, dan sebagainya (Kosasih, 2005: 99).

\section{b. Tokoh (Characterization)}

Tokoh adalah individu ciptaan/rekaan pengarang yang mengalami peristiwa-peristiwa atau lakuan dalam berbagai peristiwa cerita. Pada umumnya tokoh berwujud manusia, namun dapat pula berwujud binatang atau benda yang diinsankan. Tokoh sentral adalah tokoh yang banyak mengalami peristiwa dalam cerita. Tokoh sentral dibedakan menjadi dua, yaitu:

1) Tokoh sentral protagonis, yaitu tokoh yang membawakan perwatakan positif atau menyampaikan nilai-nilai positif.

2) Tokoh sentral antagonis, yaitu tokoh yang membawakan perwatakan yang bertentangan dengan protagonis atau menyampaikan nilai-nilai negatif.

\section{c. Penokohan atau perwatakan}

Penokohan merupakan penggambaran suatu watak tokoh dalam sebuah novel. "Tokoh tersebut digambarkan mempunyai karakter atau sifat, misalnya pemarah, periang, pemabuk, atau rajin. Penggambaran watak tokoh dapat secara langsung ataupun tidak langsung." (Syamsuddin, 2005: 98).

\section{d. $\quad$ Alur (Plot)}

Tema merupakan pola pengembangan cerita yang terbentuk oleh hubungan sebab-akibat (Kosasih, 2006: 83). Tema adalah jalinan cerita yang dibuat oleh pengarang dalam menjalin kejadian secara beruntun atau rangkaian/jalinan antar peristiwa/ lakuan dalam cerita. Sebuah cerita sebenarnya terdiri dari berbagai peristiwa yang memiliki hubungan sebab- akibat. Jalinan itu yang dinamakan alur/plot. Alur dapat dikategorikan menjadi tiga :

1) Alur maju atau progresif (alur lurus) Rangkaian peristiwanya bergerak maju dari awal ke akhir (kronologis)

2) Alur mundur atau regresif (flashback) Rangkaian peristiwanya bergerak mundur dari akhir ke awal (set back)

3) Alur campuran (maju-mundur) Rangkaian peristiwa bergerak secara acak.

\section{e. Latar (Setting)}

Latar adalah segala keterangan, petunjuk, pengacuan yang berkaitan dengan waktu, ruang, dan situasi terjadinya peristiwa dalam suatu karya sastra beserta tempatnya (Syamsuddin, 2005: 99). Latar dapat dibedakan ke dalam dua unsur pokok:

1) Latar tempat, mengacu pada lokasi terjadinya peristiwa yang diceritakan dalam sebuah novel. 
2) Latar waktu, berhubungan dengan masalah „kapan ${ }^{\text {ee }}$ terjadinya peristiwa-peristiwa yang diceritakan dalam sebuah novel.

3) Latar suasana, suasana adalah salah satu unsur intrinsik yang berkaitan dengan keadaan psikologis yang timbul dengan sendirinya bersamaan dengan jalan cerita. Suatu cerita menjadi menarik karena berlangsung dalam suasana tertentu. Misalnya, suasana gembira, sedih, tegang, penuh semangat, tenang, damai, dan sebagainya. Suasana dalam cerita biasanya dibangun bersama pelukisan tokoh utama. Pembaca mengikuti kejadian demi kejadian yang dialami tokoh utama dan bersama dia pembaca dibawa larut dalam suasana cerita.

4) Sosial budaya, Sosial budaya ialah latar pergaulan dalam status sosial. Latar ini berkaitan erat dengan latar tempat karena ada hubungannya dengan tempat bergaul.

5) Keadaan lingkungan, Latar ini menceritakan konflik batin yang dialami oleh tokoh melalui pengaruh lingkungan sekitarnya.

\section{f. Sudut Pandang (Point of Viuw)}

Sudut pandang atau titik pengisahan adalah posisi pengarang dalam membawakan cerita (Kosasih, 2006: 83). Posisi pengarang ini terdiri atas dua macam :

1) Sudut pandang orang pertama

Pada sudut pandang orang pertama, posisi pengarang berada di dalam cerita. Ia terlibat dalam cerita dan menjadi salah satu tokoh dalam cerita (bisa tokoh utama atau tokoh pembantu). Salah satu ciri sudut pandang orang pertama adalah penggunaan kata ganti ,akue dalam cerita. Oleh karena itu, sudut pandang orang pertama sering disebut juga sudut pandang akuan.

2) Sudut pandang orang ketiga

Pada sudut pandang orang ketiga, pengarang berada di luar cerita. Artinya dia tidak terlibat dalam cerita. Pengarang berposisi tak ubahnya seperti dalang atau pencerita saja. Ciri utama sudut pandang orang ketiga adalah penggunaan kata ganti ,dia ${ }^{\text {ee }}$ atau nama-nama tokoh ${ }^{\mathrm{ee}}$.

\section{g. Gaya Bahasa (Language Style)}

Gaya bahasa adalah cara pengarang mengungkapkan ceritanya melalui bahasa yang digunakan. Setiap pengarang memiliki gaya masing-masing. Gaya bahasa berfungsi sebagai alat utama pengarang untuk melukiskan, menggambarkan, dan menghidupkan cerita secara estetika. misalnya personifikasi, gaya bahasa ini mendeskripsikan benda-benda mati dengan cara memberikan sifat-sifat seperti manusia. Simile (perumpamaan), gaya bahasa ini mendeskripsikan sesuatu dengan pengibaratan. Hiperbola, gaya bahasa ini mendeskripsikan sesuatu dengan cara berlebihan dengan maksud memberikan efek berlebihan.

"Gaya bahasa berfungsi untuk menciptakan suatu nada atau suasana persuasif, serta merumuskan dialog yang mampu memperlihatkan hubungan dan interaksi antara sesame tokoh. Kemampuan sang penulis mempergunakan bahasa 
secara cermat dapat menjelmakan suatu suasana yang berterus terang atau satiris, simpatik atau menjengkelkan, dan objektif atau emosional" (Kosasih, 2006 : 84).

\section{h. Amanat (Mandate)}

Amanat merupakan ajaran moral atau pesan yang hendak disampaikan pengarang kepada pembaca melalui karyanya itu (Kosasih, 2006: 84). Amanat adalah pesan yang ingin disampaikan pengarang kepada pembaca. Amanat dalam cerita bisa berupa nasihat, anjuran, atau larangan untuk melakukan/tidak melakukan sesuatu. Suatu cerita yang amanat dalam pasti mengandung pesan yang bersifat positif.

\section{Unsur Ekstrinsik Novel}

Unsur ekstrinsik ialah unsur luar yang membangun sebuah novel. Unsur tersebut tidak dapat ditemukan dalam novel. Walaupun unsur ekstrinsik berasal dari luar novel namun tetap berpengaruh dalam karya ini. Dibawah ini terdapat beberapa unsur ekstrinsik novel beserta penjelasannya.

\section{a. Unsur Biografi}

Unsur ekstrinsik novel yang pertama ialah unsur biografi. Unsur biografi ialah unsur mengenai latar belakang pengarang, misalnya latar belakang keluarga, lingkungan, tempat tinggal, pendidikan, dan lain lain. Latar belakang tersebut sangat penting dalam menulis novel, contohnya jika latar belakang penulis berasal dari keluarga miskin maka biasanya akan membuat novel yang memiliki cerita yang menyentuh hati pembacanya.

\section{b. Unsur Sosial}

Unsur ekstrinsik novel selanjutnya ialah unsur sosial. Unsur sosial ialah jenis unsur yang berkaitan dengan keadaan masyarakat disaat novel dibuat. Misalnya pembuatan novel terjadi dimasa Orde Baru. Saat itu pemerintah dalam keadaan acak acakan dan kacau, maka novel dibuat dengan maksud menyindir.

\section{c. Unsur Nilai}

Unsur ekstrinsik novel yang terakhir ialah unsur nilai. Unsur nilai berhubungan dengan ekonomi, sosial, pendidikan, adat istiadat, politik, seni, hukum dan lain lain. Nilai yang terdapat dalam novel tersebut merupakan daya tarik tersendiri untuk pembaca. Bahkan cukup mempengaruhi baik atau tidak dari cerita novel tersebut.

\section{KESIMPULAN}

Tindak tutur dalam novel terbagi dalam lima kelompok tindak ilokusi, yakni representatif, direktif, komisif, ekspresif, dan isbati. Karakteristik tuturanguna mewujudkan kesantunan berbahasa dalam novel terdapat: (1) menggunakan tawaran, (2) memberi pujian, (3) menggunakan tuturan tidak langsung, dan (4) meminta maaf. Ketiga, strategi penutur dalam mewujudkan kesantunan berbahasa: (1) menolak, (2) memerintah, (3) menawarkan, dan (4) meminta, (5) melarang, (6) memuji, dan (7) meminta maaf.

Pemilihan tuturan-tuturan dalam novel oleh seorang pengarang merupakan fenomena yang menarik dalam perkembangan bahasa ketika dilihat dari sudut pandang kesantunan berbahasa. Kajian mengenai realisasi kesantunan setidaknya 
dapat menambah ilmu bagi peneliti lain yang ingin mengembangkan lebih lanjut kajian berkenaan dengan kesantunan berbahasa.

\section{DAFTAR PUSTAKA}

Alisjahbana, S. Takdir. 1984. Perjuangan tanggung Jawab dalam Kesustraaan. Jakarta Pustaka Jaya.

Alviah, Iin. 2014. Kesantunan Berbahasa Dalam Tuturan Novel Para Priyayi Karya Umar Kayam. Seloka: Jurnal Pendidikan Bahasa. https://www.google.com/search?q=daftar+pustaka+Riniwati+(2004+tentang + sastra\&rlz=1C1CHBD_enID849ID849\&oq=daftar+pustaka+Riniwati+(20 04+tentang+sastra\&aqs=chrome..69i57.1501j0j9\&sourceid=chrome\&ie=UT F-8. Diakses 23 Oktober 2019.

Alwasilah, A. Chaedar. 1993. Pengantar Sosiolinguistik Bahasa. Bandung: Angkasa.

Austin, J.L. 1962. How to Do Things with Words. London: Oxford University Press.

Budiyati, 2009. Silabus, Handout dan Media Pembelajaran Apresiasi Drama. Semarang: UNNES

Fananie, Zainuddin. 20004. Telaah Sastra. Surakarta: Muhammadiyah University Press.

http://id.wikipedia.org/wiki/Sastra. Diakses 10 Oktober 2018.

http://www.e-jurnal.com/2018/11/pengertian-novel-menurut-para-ahli.html.

Diakses 15 Oktober 2018.

Kayam, Umar. 1992. Para Priyayi. Jakarta: PT. Pustaka Utama Grafiti.

Kosasih, Engkos. 2006. Cerdas Berbahasa Indonesia. Jakarta : Erlangga.

Leech, Geoffrey. 1993. Prinsip-prinsip Pragmtik (Diterjemahkan oleh Oka). Jakarta: Balai Pustaka.

Lexy J. Moleong. 2006. Metodologi Penelitiann Kualitatif Edisi Revisi, Cetakan keduapuluh dua, Bandung: PT. Remaja Rosdakarya Offset.

Rahardi, Kunjana. 2000. Imperatif dalam Bahasa Indonesia. Yogyakarta: UGM.

Rahardi, Kunjana. 2008. Pragmatik: Kesantunan Imperatif Bahasa Indonesia. Yogyakarta: PT Gelora Aksara Pratama.

Sawali dalam otonomi pengajaran sastra (htttp://sawali.info/2007/07/15/otonomipengajaran-sastra/. diakses tanggal 22 Oktober 2018).

Syamsuddin. A.R. 2005. Cerdas Berbahasa Dan Sastra Indonesia. Solo : PT Tiga Serangkai Pustaka Mandiri.

Tresnawati, Tjetje. 1998. Tindak Tutur Percakapan dalam Novel Sekayu Karya Nh. Dini. Tesis. Semarang: IKIP Semarang.

Wijana, I Dewa Putu \& Rohmadi. Muhammad. 2009. Analisis Wacana Pragmatik: Kajian Teori dan Analisis. Surakarta: Yuma Pustaka. 